\title{
THE LEGALITY OF PROVIDING LEGAL AID TO PERPETRATORS OF THE CRIME OF MURDER IN THE PERSPECTIVE OF THE THEORY OF DIGNIFIED JUSTICE
}

\author{
Muhlis Safi'i \\ Faculty of Law, Universitas Negeri Semarang, Indonesia \\ *Email: safii_muhlissa@students.unnes.ac.id
}

The Unitary State of the Republic of Indonesia is a state of law. In accordance with Article 1 paragraph (3) of the 1945 Constitution (UUD 1945). As a state of law, Indonesia must guarantee the rights of its citizens to equality and guarantees of justice, including human rights. As stated by Salim, quoting Fredrich Julius Stahl, that the main element of a state based on law is the protection, as well as the recognition of Human Rights (HAM), and upholding dignified justice. Also in Article $28 D$ paragraph (1) of the 1945 Constitution (UUD 1945) which reads: "Everyone has the right to recognition, guarantees, protection and fair legal certainty and equal treatment before the law". This means that the constitution itself has accommodated, the state guarantees the fulfillment of individual rights of citizens and is treated equally before the law. In a state of law, law is used as the main shield in the movement of government, state, and society. As an effort to realize justice and spiritual

The Indonesian Journal of International Clinical Legal Education DOI: https://doi.org/10.15294/ijicle.v3i4.48275

Submitted: Dec 12, 2020 Revised: March 13, 2021 Accepted: August 10, 2021 Available online at https://journal.unnes.ac.id/sju/index.php/iccle (C) 2021 Authors. This work is licensed under a Creative Commons AttributionShareAlike 4.0 International License (CC BY-SA 4.0). All writings published in this journal are personal views of the authors and do not represent the views of this journal and the author's affiliated institutions. 


\section{Muhlis Safi'i}

values of humanity (fair and dignified), there is assistance in the form of legal services for every citizen. the existence of a dignified justice theory is a justice provided by a legal system that has spiritual and material dimensions. This theory is a theory of justice that is based on noble values that are rooted in the second principle of Pancasila, "Just and Civilized Humanity" and is inspired by the first principle, "Belief in the One Supreme God". The value of justice based on humanity and God (causa prima) will create legal justice that humanizes humans.

Keywords: Legal Aid; Justice Theory; Dignified Justice; Fair.

\section{INTRODUCTION}

The Unitary State of the Republic of Indonesia is a state of law. In accordance with Article 1 paragraph (3) of the 1945 Constitution (UUD 1945). ${ }^{1}$ As a state of law, Indonesia must guarantee the rights of its citizens to equality and guarantees of justice, including human rights. As stated by Salim, quoting Fredrich Julius Stahl, that the main element of a state based on law is the protection, as well as the recognition of Human Rights (HAM), and upholding dignified justice. ${ }^{2}$ Also in Article 28D paragraph (1) of the 1945 Constitution (UUD 1945) which reads: "Everyone has the right to recognition, guarantees, protection and fair legal certainty and equal treatment before the law". This means that the constitution itself has accommodated, the state guarantees the fulfillment of individual rights of citizens and is treated equally before the law.

In a state of law, law is used as the main shield in the movement of government, state, and society. As an effort to realize justice and human values that are spiritual (fair and dignified), there is assistance in the form of legal services for every citizen of a legal case, whether civil, criminal, or state administration. ${ }^{3}$ However, it seems that legal services are not evenly distributed and are only felt by high-class people who can get the help of legal experts.

To overcome the unequal distribution of Legal Aid services for underprivileged communities, the state must make regulations to fulfill the rights of the community to obtain access to Legal Aid. Law Number 16 of 2011 concerning Legal Aid was issued by the government with the

1 The Constitution of the Republic of Indonesia (UUD 1945) Article 1 paragraph (3)

2 Salim, HS \& Nurbani, ES (2016). Application of Legal Theory in Dissertation and Thesis Research (Third Book). Jakarta: PT. Rajagrafindo Persada

3 Law Number 16 of 2011 concerning Legal Aid Article 4 
aim of providing legal aid services to the poor and needy people for free (legal aid). ${ }^{4}$ Meanwhile, Law No. 18 of 2003 concerning Advocates also emphasizes that an advocate is required to provide legal assistance to underprivileged communities free of charge based on the conditions stipulated in the law. ${ }^{5}$ In addition, if an advocate does not carry out his obligations, he will be subject to sanctions in accordance with the provisions of the advocate profession. ${ }^{6}$ The legal services provided by advocates in assisting their clients are providing legal consultation, exercising the power given by their clients, representing and accompanying, defending, and taking other legal actions for the legal interests of their clients. $^{7}$

In the perspective of criminal law, legal entities or community organizations are a form of embodiment of the accusatoir principle in the Criminal Procedure Code. The accusatoir principle is a principle that shows that a defendant who is examined in a court trial is no longer an object of examination, but as a subject. This principle stipulates that the examination process is carried out openly, where everyone can witness the examination of the accused.

Legal Aid is a legal service provided by Legal Aid Providers free of charge to Legal Aid Recipients. ${ }^{8}$ Legal Aid is also a form of responsibility of the State, Government, Society, Community Organizations, and all parties in society such as advocates, paralegals, and the like. ${ }^{9}$ In Government Regulation Number 83 of 2008, concerning the Requirements and Procedures for Providing Legal Aid, it is defined that an advocate is a person who has the profession of providing legal services, both in court and out of court, who fulfills the provisions based on Law Number 18 of 2003 concerning Advocates. While the legal services in question are services provided by advocates in the form of providing legal consultation, exercising the power given by their clients, representing and accompanying, defending, and taking other legal actions for the legal interests of their clients. ${ }^{10}$

The criminal case of murder is one of the crimes that require legal assistance. Article 60 of the Criminal Procedure Code (KUHAP) stipulates that a defendant or suspected criminal has the right to receive visits from parties who have family relationships to obtain legal assistance. Legal assistance is very important for suspects or defendants in facing the case process. The existence of assistance is based on the importance of protecting human beings as legal subjects of law enforcement. For suspects who are poor, it is stated in the case process,

\footnotetext{
Law Number 16 of 2011 concerning Legal Aid Article 1

Law Number 18 of 2003 concerning Advocates Article 22 paragraph (1)

Law Number 18 of 2003 concerning Advocates Article 6

Law Number 18 of 2003 concerning Advocates Article 22 paragraph (1)

Law Number 16 of 2011 concerning Legal Aid Article 1 paragraph (1)

Law Number 16 of 2011 concerning Legal Aid

Ibid.
} 


\section{Muhlis Safi'i}

investigators are obliged to provide legal advisory services for poor criminal suspects/defendants in accordance with Article 56 paragraph (1) of the Criminal Procedure Code.

Based on the descriptions above, a common thread can be drawn that will be discussed in this article, namely how the legality of providing legal aid for perpetrators of the crime of murder in the perspective of the theory of dignified justice. ${ }^{11}$ Referring to the formulation of the problem above, this article aims to describe and analyze the legitimacy of providing legal aid for the perpetrators of the crime of murder in the perspective of the theory of dignified justice.

This research is expected to provide contributions and additional insights both practically and theoretically.

\section{Practical Benefits}

This research is expected to be a reference for consistent research in the future. And become a consideration for legal entities or the community in implementing Legal Aid.

\section{Theoretical Benefits}

This research is expected to contribute and increase the knowledge base in the field of legal aid in relation to the implementation of legal aid for the perpetrators of the crime of murder, as well as strengthening the legal norms of society.

Legal research is a form of scientific activity based on systematic methods and thinking to examine certain legal

11 Legal reform or also often referred to as legal reform in Indonesia is not just changing, growing, correcting, reviewing, replacing or completely erasing the provisions of legal rules and principles in law and the provisions of laws and regulations that apply in a legal system. the spirit in law, manifesting through the modification, addition, replacement or elimination of a provision, rule or legal principle in the laws and regulations that apply to a legal system so that the relevant legal system becomes better, more just, useful and more certain. according to law. The theory of dignified justice is a legal theory initiated by Prof. Teguh Prasetyo, a legal theory that departs from the system postulate; work to achieve the goal, namely justice with dignity, justice that humanizes humans. The theory of dignified justice is an activity of philosophical thinking, one of which is carried out by the judge when the judge gives legal considerations for his decision. Judges in giving consideration to their decisions must approach the law philosophically, namely by thinking radically. Thinking radically is thinking up to the essence, essence or to the substance that is thought. Please see Tri Astuti Handayani, "Bantuan Hukum bagi Masyarakat Tidak Mampu dalam Perspektif Teori Keadilan Bermartabat." Refleksi Hukum: Jurnal Ilmu Hukum Vol. 9 No.1, 2015, pp. 15-24; Teguh Prasetyo, "Initiating Law Reform in Indonesia (From the Dignified Justice Perspective)." Jurnal Hukum Magnum Opus Vol. 3 No. 1, 2020, pp. 14-25; I. Nyoman Dipa Rudiana, and I. Ketut RAI Setiabudhi. "Reconstruction of the Diversion Concept in a Child Criminal Jurisdiction System Based on Dignified Justice." Prizren Social Science Journal Vol. 5 No. 1, 2021, pp. 104-112; Tri Astuti Handayani, " Paralole in Penitentiary System Viewed from Theory of Dignified Justice." Surakarta Law and Society Journal Vol. 2 No.1, 2019, pp. 20-32. 
phenomena. ${ }^{12}$ The type of research used in this paper is library research, which in collecting data the author uses written documents as data material. Library research is research that is carried out using literature (library), in the form of books, notes, and reports of previous research results. ${ }^{13}$ This study uses written documents as data, and the data sources used in this study include primary legal materials, and secondary legal materials. Primary legal materials are legal materials that are binding and obedient to all legal objects in the form of legal products, which include Law No. 16 of 2011 on Legal Aid, and Law No. 18 of 2003 on Advocates. Secondary legal materials are explanations of primary legal materials, or the essence of legal opinions obtained from books, legal principles, doctrines, and official agency data. ${ }^{14}$

\section{LEGAL AID: DEFINITION AND LIMITATION IN THE PRACTICES}

Legal Aid is a legal service provided by Legal Aid Providers free of charge to Legal Aid Recipients. ${ }^{15}$ According to Sukinta, there are two models that describe legal aid, namely legal aid and legal assistance. The term legal aid is usually used to describe legal aid in a narrow sense, where legal aid is defined as the provision of services in the legal field to someone who is involved in a case, especially for the poor and is given free of charge. In this case:

1. Provide services free of charge,

2. Providing legal aid services for the poor and marginalized,

3. The motivation for providing legal aid is to enforce legal aid by defending the interests and rights of marginalized and less educated people about the law.

Meanwhile, legal assistance is commonly used to describe complex and broad legal assistance. In addition to providing Legal Aid to underprivileged communities, it also provides Legal Aid services by Advocates who have legal expertise and provide legal assistance using the payment of a sum of money from clients, who are Legal Aid Recipients. ${ }^{16}$ If we examine further about the two models, it can be concluded that in the provision of Legal Aid, one party provides services

12 Soekanto, S., \& Mamudji, S. (2003). Normative Legal Research: A Brief Overview. King Grafindo Persada

13 IqbaI Hasan (2008), Analysis of Research Data With Statistics, Jakarta: Earth Literacy.

14 Ronny Hatnijo Soemitro (1990), Legal Research Methodology and Surveyor, Jakarta: Ghalia Indonesia.

15 Law Number 16 of 2011 concerning Legal Aid Article 1 paragraph (1)

16 Sukinta (1997), The Role of Legal Aid Institutions for the Community in Obtaining Justice (Faculty of Law at Diponegoro University) 


\section{Muhlis Safi'i}

and protects one's interests and on the other hand becomes a shield in the welfare of the community.

The definition of Legal Aid can also be seen in Law Number 16 of 2011 concerning Legal Aid, in Article 1 paragraph (1) it is stated that Legal Aid is a legal service provided by Legal Aid Providers free of charge to Legal Aid Recipients. Furthermore, regarding the object or Legal Aid Recipients, it is emphasized in Article 1 paragraph (2), that the recipients of Legal Aid are poor people or groups of people. And Legal Aid Provider is a legal entity or community organization that provides legal services based on this statutory regulation.

What is meant by the services provided in Legal Aid, among others:

1. Provide advice in relation to the case,

2. Act as a companion or counselor for the accused or perpetrator of a crime. Here the role of defending and providing direction about the problem and direction of the case.

In Law Number 18 of 2003 concerning Advocates, it is stated that legal aid is a service provided by an advocate free of charge which is given to clients who cannot afford it. Meanwhile, Government Regulation Number 88 of 2008 concerning the Provision of Free Legal Aid states that legal services provided without an advocate are provided without receiving an honorarium, including providing legal consulting services, exercising power of attorney, representing and accompanying, defending, and taking legal action on the interests of clients., which incidentally is the poor.

Meanwhile, Todung Mulya Lubis in his book Legal Aid and Structural Poverty provides an opinion related to traditional and individual Legal Aid. Among them:

1. Traditional and individual legal aid has a healing nature, meaning that the assistance does not seek a cure and causes people to lose their rights.

2. A legal system that still supports traditional and individual forms of legal aid, which in the process of resolving cases focuses on the courts and not externally,

3. Urban nature. Legal experts provide assistance services in urban areas, and are generally still rarely found and reached in rural areas,

4. It is passive, meaning that legal experts wait when the community realizes their lost rights and recognizes them.

5. Too gripping on technical legal approaches, not on how to properly handle conflicts.

6. Its implementation still relies on its own services, and has not collaborated with legal aid organizations or institutions that are considered appropriate and a solution to reduce the conflict 
7. Generally, legal aid runs without creating currents, where the assistance provided to the community is not yet connected to harmonious power resources. ${ }^{17}$

\section{FUNCTIONS AND OBJECTIVES OF LEGAL AID IN PROVIDING JUSTICE}

In essence, the implementation of Legal Aid aims to ensure the welfare of the community through the fulfillment of access to legal aid. This is in accordance with Article 3 of Law Number 16 of 2011 concerning Legal Aid, namely:

a. Guarantee and fulfill the rights of Legal Aid Recipients to get access to justice,

b. Realizing the constitutional rights of all citizens in accordance with the principle of equality in law,

c. Ensuring certainty that the implementation of Legal Aid is carried out evenly in the territory of the Republic of Indonesia, and

d. Realizing an effective, efficient and accountable judiciary.

Basically, the provision of legal assistance to the community includes matters of civil law, criminal law, and even the realm of state administrative law which is provided by litigation and non-litigation. This is in accordance with Article 4 of Law Number 16 of 2011 concerning Legal Aid which reads:

(1) Legal aid is given to Legal Aid Recipients who are facing legal problems,

(2) Legal Aid as referred to in paragraph (1) includes civil, criminal, and state administrative law, both litigation and non-litigation.

(3) Legal Aid as referred to in paragraph (1) includes exercising power of attorney, accompanying, representing, defending, and/or taking other legal actions for the legal interest of the Legal Aid Recipient ${ }^{18}$.

Then in Law Number 16 of 2011 concerning Legal Aid, the difference between legal aid in general and Legal Aid for the poor is in the Legal Aid Recipient, in Article 5 explains:

(1) Recipients of Legal Aid as referred to in Article 4 paragraph (1) include any person or group of poor people who cannot fulfill their basic rights properly and independently,

(2) The basic rights as referred to in paragraph (1) include the right to food, clothing, health services, education services, employment, and business, and/or housing.

By looking at the nature and purpose of the Legal Aid, it can be concluded that the existence of Legal Aid is based on the fulfillment

17 Todung Mulya Lubis (1986), Legal Aid and Structural Poverty (LP3ES 1986)

18 Law Number 16 of 2011 concerning Legal Aid Article 4 


\section{Muhlis Safi'i}

of access to justice and awareness of rights as Indonesian Citizens $(\mathrm{WNI}){ }^{19}$

\section{PROVIDING LEGAL AID AS A CONSTITUTIONAL RIGHT FOR CITIZENS}

Legal aid is a form of the Indonesian state's efforts to improve access to justice for the poor and outsiders. Sometimes the rich do not need legal assistance compared to the poor who have safer legal protection, sometimes even creating a distance of justice between the rich and the poor. $^{20}$

Based on Article 28D paragraph (1) of the 1945 Constitution (UUD 1945) the State guarantees equal rights before the law (the principle of equality before the law) and guarantees fair legal certainty including legal aid which is a constitutional right for every citizen. Indonesian (WNI). Equality for citizens before the law must be accompanied by equal treatment. ${ }^{21}$ Therefore, we need to overhaul the clearly unfair structure and replace it with a more just relationship pattern. $^{22}$

In the concept of access to justice, justice is defined as a condition and process in which the state guarantees the fulfillment of basic rights for its citizens, namely basic rights based on the 1945 Constitution, as well as universal principles of human rights and guaranteeing access for every citizen to be able to access justice. have the ability to know, understand, realize and use these basic rights through formal and informal institutions supported by a good and responsive public complaint mechanism in order to obtain optimal benefits and improve the quality of their own lives. Law Number 16 of 2011 concerning Legal Aid here also makes legal aid institutions an access to justice for people who can't afford it even for people who are legally blind.

Rawls provides the concept of social justice which is seen as a standard and distributive aspect of the basic structure of society. ${ }^{23}$ Rawls's theory of justice departs from the intuitive belief that he puts it in a long proposition whose main points are:

19 Law Number 16 of 2011 concerning Legal Aid Article 5

20 Abdul Hakim Garuda Nusantara and Mulya W. Kusumah (1981). Some Thoughts on Structural Legal Aid (Alumni 1981)

21 Moh. Isyrad Tamrin and M. Farid (2010), Guide to Legal Aid for Legals. Yogyakarta: LBH Yogyakata

22 Abdul Khakim and Mulyana W (1981) Some Thoughts on Legal Aid (Towards Structural Legal Aid). Bandung: Alumni

23 Rawls John. A Theory Of Justice (Theory of Justice). 2nd Edition(2011) Bandung: Faithful Library 
(1) Justice is the primary virtue of social institutions, as is truth in our system of thought. Laws or institutions, however good and efficient, if they are unfair, must be corrected or abolished. Right and justice are things that cannot be compromised,

(2) Everyone has rights that are embedded in the principle of justice that should not be violated even in the name of the public interest. Justice does not justify the sacrifice of the interests of a person or group of people for the benefit of the people.

(3) In a just society, independence is automatically guaranteed; the rights guaranteed by justice cannot fall prey to political bargaining or public interest calculations.

(4) Injustice can be tolerated only when necessary to avoid greater injustice.

In order to increase legal awareness and access to justice as an implementation of guarantees for the legal protection of the poor. There are forms of Legal Aid and its access for the poor.

1. Law Number 48 of 2009 concerning Judicial Power Article 56:

(1) Everyone involved in a case has the right to obtain legal assistance,

(2) The state bears the costs of the case for justice seekers who cannot afford it.

Article 57:

(1) At each district court a legal aid post is established for justice seekers who are unable to obtain legal assistance,

(2) The legal aid as referred to in paragraph (1) is provided free of charge at all levels of the judiciary until the decision on the case has permanent legal force.

(3) The legal aid and legal aid post as referred to in paragraph (1) shall be carried out in accordance with the provisions of the legislation.

2. Law Number 8 of 1981 concerning the Criminal Procedure Code (KUHAP)

(1) Article 56 paragraph (1)

To state that a suspect or defendant who is suspected or accused of committing a criminal act which is punishable by the death penalty or a sentence of fifteen years or more from or for those who are incapacitated is threatened with a sentence of five years or more who has no law of his own, the official concerned at all level of examination in the judicial process is obliged to appoint legal counsel for them.

(2) Article 56 paragraph (2)

The legal advisor appointed to act as referred to in paragraph (1) shall provide his assistance free of charge.

(3) Article 144 


\section{Muhlis Safi'i}

A person suspected of committing a crime prior to the commencement of the examination process by the investigator, the investigator is required to grant the right of the "suspected" criminal act suspect to obtain legal assistance, which must be accompanied by legal counsel.

Talking about judges Talking about judges and judges' decisions in Indonesia, cannot be separated from talking about justice. Access to justice is a form of embodiment of the principle of the rule of law and the recognition of human rights as guaranteed in the 1945 Constitution of the Republic of Indonesia. The rights and obligations of Indonesian citizens are expected to become a unified whole. aims to realize a just Indonesia in accordance with the precepts of social justice for all Indonesian people. The concept of access to justice has a social justice goal that prevents real poverty as an effort to have affirmative action against vulnerable groups or poor groups.

\section{LEGAL BASIS FOR PROVIDING LEGAL AID FOR CRIMINALS}

Indonesia strictly enforces the Criminal Procedure Code (KUHAP) that regulates the rights of suspected perpetrators of criminal acts, which can guarantee and protect perpetrators from arbitrary practices. A suspect is a person who because of his actions or circumstances, based on preliminary evidence, should be suspected as a criminal act. ${ }^{24}$ Guarantees of Human Rights (HAM) are absolute and place Human Rights (HAM) against the suspect placing the examination process and case process upholding human values and rights for suspects (dignity justice). Perpetrators have the right to contact legal counsel, receive doctor visits for their personal interests, have the right to notify their family, relatives, and friends regarding their detention in providing legal assistance and/or adjournment of their detention.

Legal advisors provide legal assistance and advice either directly or indirectly in a case, generally legal advisors as lawyers, advocates and practicing lawyers. ${ }^{25}$ Law Number 18 of 2003 defines advocates or legal advisors to provide legal services both outside and during court proceedings as long as they follow the provisions of this law.

24 The Criminal Procedure Code Article 1 point (14)

25 Bambang Waluyo (2008), Criminal and Criminal. Jakarta: Sinar Graphic Publisher 


\section{A. The Suspect's Right to Obtain Legal Assistance in the Investigation Process}

Under certain conditions, a person suspected of being a "suspect" may have coercion over the investigator's power.

1. Arrests and detentions are carried out based on sufficient evidence (Article 17 of the Criminal Procedure Code)

2. Detention is only for the sake of investigation, prosecution, and trial in court (Article 20 of the Criminal Procedure Code)

3. Detention has a time limit (Article 20 of the Criminal Procedure Code)

4. The detention order must be based on evidence that the defendant is afraid that the defendant will run away, damage and/or damage evidence or his actions (Article 21 paragraph (1) of the Criminal Procedure Code)

5. Detention must meet the criteria and provisions of a valid administrative procedure and carried out by an authorized official (Article 21 paragraph (2) and paragraph (3) and Article 24-28 of the Criminal Procedure Code)

6. Detention is facultative, except for certain crimes (Article 20 paragraph (4) KUHAP)

7. The length of detention must be deducted from the length of the sentence imposed on the suspect (if it is proven that he has committed the crime he is accused of)

8. While in detention the suspect must be treated humanely and not allowed to be tortured, or under pressure that degrades his dignity as a human being (Article 66, Article 117, and Article 122 of the Criminal Procedure Code).

9. Within 24 hours after being detained, the suspect must be examined, but in practice it is not determined whether the examination is 1,2 , or more. Provisions that support a fast, precise, and simple trial.

The role of providing legal assistance for a suspect to defend himself if his rights as a human being are violated, also if there will be and have caused various deviations due to the use of investigator power that is too large and tends to be in ways that are no longer controlled. The investigation process in providing legal advocacy to suspects is emphasized on protecting the rights of suspects.

Legal counsel must be able to protect every right that the suspect needs in the examination. Against suspects who have been detained by investigators. For suspects who are already in the process of being detained, suspect investigators have the following rights:

1. The right to contact legal counsel.

2. The right to contact and receive personal doctor visits for health purposes, whether or not related to the case process. 


\section{Muhlis Safi'i}

3. The suspect has the right to be notified of his detention to his family, to people who live with him, other people whose assistance is needed, and people who wish to provide legal assistance or guarantees for the suspension of his detention.

4. As long as the suspect is in detention, he has the right to contact the family, receive visits from the family.

5. The right, directly or through the intercession of legal advisers, to contact and receive relatives, both for the benefit of his family, the interests of his case and the interests of his work.

6. The right to correspondence, namely, sending and receiving letters to his legal advisor, sending and receiving letters to relatives.

7. Entitled to freedom of secret letter. It may not be examined by investigators, public prosecutors or officials of the state detention center unless there is sufficient reason to suspect that the correspondence has been misused.

8. The suspect has the right to contact and receive spiritual visits. The provision of legal assistance in the advocacy process gives legal advisors the right to always try to establish a relationship with the suspect. Legal counsel has the right to contact suspects at all levels of examination.

9. In addition, the suspect must be treated well and considered innocent until a proper legal decision is obtained (the principle of the presumption of innocence).

\section{B. The Suspect's Rights in the Case of Advocates Who Can't Provide Legal Aid}

In Providing Legal Aid. Legal aid is a concept that was born on the basis of a deep understanding of our purpose in society which actually wants to liberate the nation. since the pre-independence period until now, the issue of legal aid has always remained relevant to be studied among the major themes of other legal issues.

Legal aid will always develop along with the development of the law itself. The growing discourse and various kinds of legal aid concepts in Indonesia are actually the answer to the people's need for this. Most of the Indonesian people who are still below the poverty line and are legally illiterate encourage the growth of awareness among some who are concerned about this matter to find a powerful formula to overcome these problems. Legal aid referred to in this definition includes legal assistance in formal conflict resolution experienced by a person (suspect since the investigation level), and legal assistance outside the judicial process.

Basically, the main task of legal advisors (advocates and lawyers) in practice is to provide legal opinions, as well as legal advice in order to keep clients from conflict, while in judicial institutions 
(practice in court) legal advisors propose or defend their clients. ${ }^{26}$ In Law Number 18 of 2003 concerning Advocates there are rights that are owned by advocates, namely Advocates have the right to freely issue opinions or statements in defense of cases that are their responsibility in court trials by adhering to the professional code of ethics and laws and regulations. ${ }^{27}$

Advocates have the right to be free in carrying out their professional duties to defend cases for which they are responsible by adhering to the professional code of ethics and legislation. ${ }^{28}$

Advocates have the right to obtain information, data, and other documents, both from government agencies and other parties related to these interests, which are needed to defend the interests of their clients in accordance with the laws and regulations. ${ }^{29}$ Advocates have the right to confidentiality in their relationship with clients, including protection of their files and documents against confiscation or examination and protection against eavesdropping on Advocate's electronic communications. ${ }^{30}$

With regard to the moral responsibility of advocates and in their position as one of the pillars or buffers of the implementation of a fair and balanced judicial system (fair trial), the author agrees with the opinion which states that advocates have a role not only as defenders of the constitution but also as defenders. human rights. Therefore, advocates have a social function in carrying out their duties, therefore humans need the protection of their interests. ${ }^{31}$

The procedure for providing legal aid is regulated in Articles 14 to 19 of Law Number 16 of 2011 concerning legal aid. Including the following:

(1) To obtain legal aid, applicants for legal aid must meet the following requirements:

a. Submit a written application that contains at least the identity of the applicant and a brief description of the subject matter for which legal assistance is to be applied

b. Submit documents related to the case, and

c. Attach a certificate of poverty from the lurah, village head, or an official at the same level as the legal aid applicant's residence.

(2) In the event that the applicant for legal aid is unable to prepare a written application, the application can be submitted orally.

Then in Article 15 of Law Number 16 of 2011 confirms:

(1) Applicants for legal aid apply for legal aid to the legal aid provider

26 Suhrawardi K Lubis (2012), Ethics of the legal profession, Jakarta: Sinar Grafika

27 Law Number 18 of 2003 concerning Legal Aid Article 14

28 Law Number 18 of 2003 concerning Legal Aid Article 15

29 Law Number 18 of 2003 concerning Legal Aid Article 17

30 Law Number 18 of 2003 concerning Legal Aid Article 19 paragraph (2)

31 Sudikno Mertokusumo (2011), Capita Selekta of Legal Studies. Yogyakarta: Liberty Publishers 


\section{Muhlis Safi'i}

(2) The legal aid provider within a maximum period of 3 (three) working days from the time the application for legal assistance is declared complete must provide an answer to accept or reject the application for legal assistance.

(3) In the event that the application for legal aid is received, the legal aid provider must provide legal assistance based on a special power of attorney from the recipient of legal aid

(4) In the case that the right to apply for legal aid is rejected, the legal aid provider must state the reasons for the refusal

(5) Further provisions regarding the requirements and procedures for providing legal aid are regulated in government regulations.

In terms of funding for legal aid, according to Law Number 16 of 2011 concerning legal aid, it is regulated in several articles, including Article 16, Article 17, Article 18, and Article 19 where legal aid is provided for perpetrators/defendants/suspects who are unable to allocate budget for the provision of assistance. law in the State Revenue and Expenditure Budget (APBN).

(1) Funding for legal aid needed and used for the administration of legal aid in accordance with this law is charged to the State Revenue and Expenditure Budget (APBN).

(2) In addition to the funding as referred to in paragraph (1), legal aid funding sources can come from:

a. Grants or donations

b. Legal and non-binding sources of funding.

\section{LEGAL AID IN THE PERSPECTIVE OF DIGNIFIED JUSTICE}

The theory of dignified justice is a justice provided by a legal system that has spiritual and material dimensions. This theory is a theory of justice that is based on noble values that are rooted in the second principle of Pancasila, "Just and Civilized Humanity" and is inspired by the first principle, "Belief in the One Supreme God".

The value of justice based on humanity and God (causa prima) will create legal justice that humanizes humans, meaning that even if a person is legally guilty, he still has the opportunity to be treated as a human being properly. So that the existence of this dignified justice creates a balance between the right to humanity and the obligation to improve justice. ${ }^{32}$ The theory of dignified justice supports the policy of providing legal aid in criminal cases that is oriented to the philosophy of law for humans. This means that the law, including the regulation of legal

32 Teguh Prasetyo (2015), Dignified Justice from Legal Theory Perspective (Nusa Media 2015) 
aid for justice seekers who cannot afford it, must serve humans (https://peradi-tasikmalaya.or.id/). In reviewing the theory of dignified justice, legal aid to the poor and underprivileged must be subject to laws and regulations, for example the Law on Legal Aid and Law on Advocates.

The theory of dignified justice departs from the postulate of the system which means working towards the goal, namely dignified justice. Justice that humanizes humans, or justice that nge wong to wong. ${ }^{33} \mathrm{As}$ is known, the legal empire is the empire of reason, intention and taste of a human child, wherever he is living his life. This is in line with the principles in the theory of dignified justice which cares about taking advantage of the opportunities that God has given him to help others through thinking activities; humanize humans or nge wong to wong. The theory of dignified justice also examines the practice, enforcement or activity of the positive law that solves the problems of everyday people and society from a legal perspective, down to the deepest essence, the nature that transcends sensory knowledge.

The theory of dignified justice is not only concerned with the layers of legal foundations that appear on the surface of a legal system. The theory of dignified justice also seeks to explore and capture the layers of legal foundations that lie beneath the surface of the legal foundations of the visible legal system. The theory of dignified justice, in accordance with its philosophical characteristics, seeks to explore old values or foundations beneath the surface of the legal system foundations that appear today, as well as break down from under the colonial foundations. The foundation that has long existed in the soul of the nation by the theory of dignified justice is seen as the bottom-line of a legal system in which all the contents of the system are laid and function to pursue its goal, namely justice. ${ }^{34}$

The provision of legal aid is an embodiment of human values of respect for one's dignity, even if a person is in a condition who is unable to obtain legal assistance, he must still receive a defense from an advocate, as a manifestation of the value of equality before the law (the principle of equality before the law). The defense of legal aid recipients by advocates in providing assistance to their clients aims to enforce the rules and provide a sense of justice for perpetrators of crimes/criminal acts/suspects in following the case settlement process. The existence of an advocate also helps if the client is proven guilty, the decision handed down to the perpetrator of the crime/crime/suspect still has the value of justice and does not conflict with the norms of decency and human values. ${ }^{35}$ This form of legal service is in the form of legal services

33 Teguh Prasetyo (2013), Law and the Legal System Based on Pancasila, Yogyakarta: Media Mighty

34 Ibid.

35 Djoko prakoso (1988), Penitensier Law in Indonesia. Yogyakarta: Liberty 


\section{Muhlis Safi'i}

provided to "everyone in need" in terms of protection against legal suspicions aimed at. ${ }^{36}$

Regarding the guarantee of access to justice, apart from being explained in the 1945 Constitution, it is also explained in Law Number 39 of 1999 concerning Human Rights. Which broadly aims to increase awareness of rights and justice with dignity. Legal aid is not only given to the community. ${ }^{37}$ Legal aid through litigation is a mechanism for resolving cases through the courts using a legal approach (law approach) through authorized law enforcement officials or agencies in accordance with the laws and regulations. Meanwhile, non-litigation legal aid is a settlement mechanism outside the trial procedure, which uses mechanisms that live in communities whose forms and types vary greatly, such as ways of deliberation, peace, kinship, or customary settlements. Legal aid for litigation or legal aid with a trial route is actually expected to be the last resort effort, namely the last resort that can be done when efforts to resolve amicably and kinship do not succeed. ${ }^{38}$

In criminal cases, litigation legal assistance is given when the criminal threat of the defendant is more than 5 years in prison. This is a form of guarantee for the granting of rights for the defendant which has been accommodated by law and even at the investigation level has been given the right to be accompanied by legal counsel. The granting of this right is accommodated by the Criminal Procedure Code (KUHAP). ${ }^{39}$

The laws and regulations governing legal aid have an understanding of the laws and regulations to be directed towards serving human welfare. The law creates a dignified society is the law?? including in this case the regulation on Legal Aid for those who can't afford it?? to humanize humans. This means that the law treats and upholds human values according to the nature and purpose of life. This is because humans are noble creatures as creations of God Almighty as stated in the second principle of Pancasila, namely a just and civilized humanity, which has the value of recognizing human dignity with all its rights and obligations and getting fair treatment of humans, self, ${ }^{40}$

One form of rights guaranteed and upheld by the constitution is obtaining a defense and legal assistance. Therefore, as a recipient of legal aid, you have rights and obligations that need to be obeyed. Among them: A. Right

36 Sadjijono (2011), Chapters of Administrative Law, Yogyakarta: Laksbang Pressindo

37 Dewa Gede Tedy Sukadama (2017) The Legality of Providing Legal Aid to Suspects Who Commit Crimes in the Bali Region (Udayana University FH Thesis Research)

38 Mustika Purbaningrum Kusumawati (2016) Role and Position of Legal Aid Institutions as Access To Justice for the Poor (Legal Arena Vol 9)

39 Article 56 paragraph (1) of the Criminal Procedure Code

40 Tri Astuti Handayani, "Arrangement of Legal Aid in Criminal Cases as an Effort" Fulfilling the Rights of Incompetent Suspects or Defendants 
1. Obtain legal assistance until the legal problem is resolved and/or the case has permanent legal force, as long as the recipient of the legal aid concerned does not revoke the power of attorney

2. Obtain legal assistance in accordance with legal aid standards and/or the Advocate's Code of Ethics

3. Obtain information and documents related to the implementation of the provision of legal assistance in accordance with the provisions of the legislation.

B. Obligation

1. Submit evidence, information, and/or case information correctly to legal aid providers

2. Assist in the smooth delivery of legal aid.

\section{CONCLUSION}

This paper highlighted and concluded that the criminal case of murder is one of the crimes that require legal assistance. Article 60 of the Criminal Procedure Code (KUHAP) stipulates that a defendant or suspected criminal has the right to receive visits from parties who have family relationships to obtain legal assistance. Legal assistance is very important for suspects or defendants in facing the case process. The existence of assistance is based on the importance of protecting human beings as legal subjects of law enforcement. For suspects who are poor, it is stated in the case process, investigators are obliged to provide legal advisory services for poor criminal suspects/defendants in accordance with Article 56 paragraph (1) of the Criminal Procedure Code. Legal assistance is very important for suspects or defendants in facing the case process. The existence of assistance is based on the importance of protecting human beings as legal subjects of law enforcement. For suspects who are poor, it is stated in the case process, investigators are obliged to provide legal advisory services for poor criminal suspects/defendants in accordance with Article 56 paragraph (1) of the Criminal Procedure Code.

\section{VIII.REFERENCES}

Handayani, T. A. (2015). Bantuan Hukum bagi Masyarakat Tidak Mampu dalam Perspektif Teori Keadilan Bermartabat. Refleksi Hukum: Jurnal Ilmu Hukum, 9(1), 15-24.

Handayani, T. A. (2019). Paralole in Penitentiary System Viewed from Theory of Dignified Justice. Surakarta Law and Society Journal, 2(1), 20-32.

Hasan, I. (2008). Analisis Data Penelitian dengan Statistik. Jakarta: Bumi Aksara. 


\section{Muhlis Safi'i}

John, R. (2011). A Theory of Justice (Teori Keadilan). Bandung: Pustaka Setia.

Lubis, S. K. (2012). Etika Profesi Hukum. Jakarta: Sinar Grafika.

Lubis, T. M. (1986). Bantuan Hukum dan Kemiskinan Struktural. Jakarta: LP3ES.

Mertokusumo, S. (2011). Kapita Selekta Ilmu Hukum. Yogyakarta: Penerbit Liberty.

Nusantara, A. H. G., \& Kusumah, M. W. (1981). Beberapa Pemikiran Mengenai Bantuan Hukum Struktural. Bandung: Alumni.

Prakoso, D. (1988). Hukum Penitensier di Indonesia. Yogyakarta: Liberty

Prasetyo, T. (2015). Keadilan Bermartabat Perspektif Teori Hukum. Jakarta: Nusa Media.

Prasetyo, T. (2020). Initiating Law Reform in Indonesia (From the Dignified Justice Perspective). Jurnal Hukum Magnum Opus, 3(1), 14-25.

Republic of Indonesia. (1945). Undang-Undang Dasar Negara Republik Indonesia (UUD 1945).

Republic of Indonesia. (2003). Undang-Undang Nomor 18 tahun 2003 tentang Advokat.

Republic of Indonesia. (2011). Undang-Undang Nomor 16 tahun 2011 tentang Bantuan Hukum.

Republic of Indonesia. Kitab Undang-Undang Hukum Acara Pidana (KUHAP).

Rudiana, I. N. D., \& Setiabudhi, I. K. R. (2021). Reconstruction of the Diversion Concept in a Child Criminal Jurisdiction System Based on Dignified Justice. Prizren Social Science Journal, 5(1), 104112.

Sadjijono, S. (2011). Bab-Bab Hukum Administrasi. Yogyakarta: Laksbang Pressindo

Salim, H. S., \& Nurbani, E. S. (2016). Penerapan Teori Hukum Pada Penelitian Disertasi Dan Tesis (Buku Ketiga). Jakarta: PT. Rajagrafindo Persada.

Soekanto, S., \& Mamudji, S. (2003). Penelitian Hukum Normatif: Suatu Tinjauan Singkat. Jakarta: Raja Grafindo Persada

Soemitro, R. H. (1990). Metodologi Penelitian Hukum dan Jurumetri. Jakarta: Ghalia Indonesia.

Sukinta, S. (1997). Peranan Lembaga Bantuan Hukum Bagi Masyarakat dalam Memperoleh Keadilan. Thesis. Semarang: Universitas Diponegoro

Tamrin, M. I., \& Farid, M. (2010). Panduan Bantuan Hukum Bagi Paralegal. Yogyakarta: LBH Yogyakarta.

Waluyo, B. (2008). Pidana dan Pemidanaan. Jakarta: Penerbit Sinar Grafika 
"There is no dignity when the human

dimension is eliminated from the person. In short,

the problem with

pornography is not that it shows too much of the

person, but that it shows

far too little."

Pope John Paul II 


\section{Muhlis Safi'i}

\section{Conflicting Interest Statement}

All authors declared that there is no potential conflict of interest on publishing this article.

\section{Funding}

None

\section{Publishing Ethical and Originality Statement}

All authors declared that this work is original and has never been published in any form and in any media, nor is it under consideration for publication in any journal, and all sources cited in this work refer to the basic standards of scientific citation.

Cite this article as:

Safi'i, M. (2021). The Legality of Providing Legal Aid to Perpetrators of the Crime of Murder in the Perspective of the Theory of Dignified Justice. The Indonesian Journal of International Clinical Legal Education, 3(4), 585-604. https://doi.org/10.15294/ijicle.v3i4.48275 